\title{
Techniques and Tools for Seismic Stratigraphic Analysis and Seismic facies: Case Study in the Rift Section of Campos Basin - Brazil
}

\author{
Renata dos Santos Alvarenga ${ }^{1}$ and Juliano Kuchle ${ }^{1},{ }^{1}$ Instituto de Geociências, UFRGS
}

Copyright 2021, SBGf - Sociedade Brasileira de Geofísica

This paper was prepared for presentation during the $17^{\text {th }}$ International Congress of the Brazilian Geophysical Society held in Rio de Janeiro, Brazil, 16-19 August 2021.

Contents of this paper were reviewed by the Technical Committee of the $17^{\text {th }}$ International Congress of the Brazilian Geophysical Society and do not necessarily represent any position of the SBGf, its officers or members. Electronic reproduction or storage of any part of this paper for commercial purposes without the written consent of the Brazilian Geophysical Society is prohibited.

\begin{abstract}
We propose here an adapted methodology to perform seismic stratigraphic analysis focusing on exploration phase of sectors or basins. These methods are derivative from several proposals from more than 40 years to recent advances, but with a theoretical focus and a lack of industry fitted procedure language. So, offers a step followed way to give units, unconformities, correlations, and seismic to well tie, seismic facies and stratigraphic infill definition. This procedure may comprise any kind of theory or definition that best fits on the dataset, giving flexibility with no misunderstanding. Can be applied to any kind of sedimentary deposits recorded on seismic data, although we show here only an example on rift section of Campos Basin (due to article size limitation). This procedure may be followed by professionals and individual products can so be easily and fast integrated. From reflections terminations (onlap, downlap, toplap and erosive truncations), stratigraphic surfaces and units are defined. The infill is made by seismic facies - with rock data correlation, seismic attributes and depositional system information. Models and interpretations regarding controlling variables offer geological characterization and evolutionary models. Chronostratigraphic chart connects the whole information and gives an integrative scenario of the performed analysis.
\end{abstract}

\section{Introduction}

The seismic stratigraphy is a technique with central role on exploration, as it allows the recognition of the stratigraphic architecture of the basin, makes it possible to define models for prospecting for oil in poorly known areas, through the correlation of wells and the integration of several data sources. This paper discusses a new and adapted procedure to make seismic stratigraphic analysis using as a base the original methodology proposed by Vail \& Mitchum (1977), after reviewed by Neal \& Abreu (2009) and Kuchle \& Scherer (2010).

\begin{abstract}
Methodology
The pioneer methodology for interpreting seismic data was started by Vail \& Mitchum (1977). After discussions about Depositional Sequences, Relative changes of the sea level and chronostratigraphic significance of seismic reflections, Vail \& Mitchum (1977) proposed a procedure for interpreting stratigraphy from seismic data. This procedure consists of three stages: (1) seismic sequence analysis, (2) seismic facies analysis, and (3) sea level analysis. Neal \& Abreu (2009) proposed a framework for the hierarchy of sedimentary units observed in stratigraphic data. In this methodology, the ability to identify a relatively conformable depositional sequence is dependent for the resolution of the data being interpreted. The methodology by Neal \& Abreu (2009), allowed determining the hierarchy of the sequences in: (i) Sequences, (ii) Set of Sequences, and (iii) Composite Sequences. In this way, was possible a better prediction for the determination of the reservoirs. Kuchle \& Scherer (2010) proposed the full interpretation of reflectors on a 2D seismic panel, and the use of tectonic system tracts, as previously proposed by Prosser (1993).
\end{abstract}

The technique here presented is an adaptation and derivation from Vail \& Mitchum (1977), Neal \& Abreu (2009), and Kuchle \& Scherer (2010) methodologies. The methodology provides a sequential analysis that can be applied to all seismic data. The sequential methodology allows obtaining and interpreting data through the following flowchart, separated in five steps: (1) interpretation of reflectors, (2) definition seismic stratigraphic units, (3) definition of seismic facies, (4) characterization and interpretation of the controlling variables of the stratigraphic interval, and (5) construction of chronostratigraphic chart.

\section{Step 1: interpretation of reflectors}

The first step consists of determining reflectors. The seismic sequence is a succession of reflectors combining each other in a seismic section, separated at the top and bottom by surfaces of discontinuities characterized by a reflector of greater amplitude (Mitchum Jr. et al., 1977). Internally a sequence is constituted by reflectors. These reflectors can be differentiated by their terminations: truncation, toplap, onlap, downlap (Figure 1).

The seismic interpretation is started by tracking the patterns of the lateral continuities of reflectors with the identifying the terminations and patterns. After mapping the reflectors, the seismic stratigraphic units are delimited. 


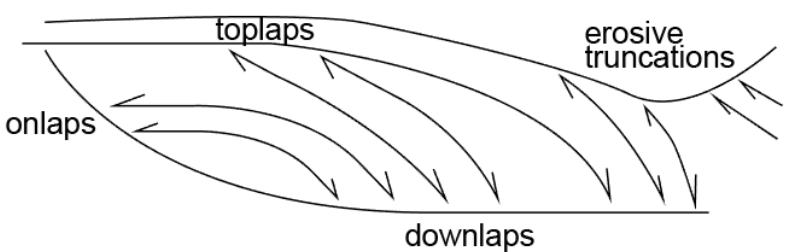

Figure 1 - Sketch of the reflectors terminations as defined by Vail et al., 1977.

For this step, here we propose a full interpretation of reflections on a $2 D$ seismic line (or a $2 D$ panel from 3D seismic volume), depositional dip oriented. Of course, a delimitation of a target stratigraphic unit of the basin can be the boundary (top and base) for the analysis. But, we strongly recommend to interpret the whole section (or interval), based on all the continuities and reflections terminations, due to offer a much more quantitative control of the reflections terminations, than just few terminations to define stratigraphic surfaces (next step).

With the whore reflections interpretation done, the seismic data is transformed by "depositional lines", as pictured originally by Vail et al. (1977), and essentially defines the philosophical stone of seismic stratigraphic interpretation. Here, we also suggest interpreting continuities and reflections terminations either from positive and negative peaks continuous traces. This is because for stratigraphic analysis does not matter if the velocity increases (positive) or decreases (negative) in a depositional bedding interface. To perform a better visual analysis, so we suggest the use of the color set red $(+) /$ white (0)/blue $(-)$ available in all seismic visualization platforms. This pallete offers a clear continuity for positive and negative peaks, and also an intensity of the continuity (or amplitude), and same weight of relevance for positive and negative reflections than the classic black/white.

\section{Step 2: definition of seismic stratigraphic units.}

The seismic stratigraphic units represent a set of chronostratigraphically related strata that present seismic expression, being delimited at the top and bottom by reflector terminations (onlaps, downlaps, toplaps and erosive truncations). These surfaces separate coherent sequences from reflector terminations and can be used like as limits of the seismic stratigraphic units. Some of these surfaces may indicate unconformity occurred within a relative period of time. The seismic stratigraphic units are composed of sets of depositional systems genetically related and arranged laterally. This is equivalent for the original Depositional System Tracts of Brown \& Fischer (1977). The tracking and mapping of a stratigraphic surface which bounds stratigraphic units is made by following several reflections terminations along a single surface, as quantitatively defined on previous step.

\section{Step 3: seismic facies characterization}

Seismic facies characterization is using to define patterns related to architectural elements, depositional systems or sedimentation environments that depending of the scale and resolution. Seismic facies was defined by Brown Jr. \& Fisher (1977) as a three-dimensional unit, with a defined area, consisting of seismic reflections whose inherent parameters differ from the adjacent facies. A seismic facies is the record in the seismic reflections of the geological factors that generate them, such as: type of lithology, stratification, depositional features, etc. The analysis of seismic facies is done through the geological interpretation and description of the seismic reflection parameters, being the continuity, configuration, amplitude, frequency of the reflectors and interval speed (Mitchum Jr. et al., 1977 - Figure 2). The analyzed parameters are correlated to the intervals that contain rock data to give robustness to the defined seismofacies. The spatial arrangement of the seismic stratigraphic units can be shows the architectural arrangement of the depositional systems during the interval filling. The stacking of the units through the definition of their relative age allows developing a temporal control, with the provision of a chronostratigraphic chart of the section.

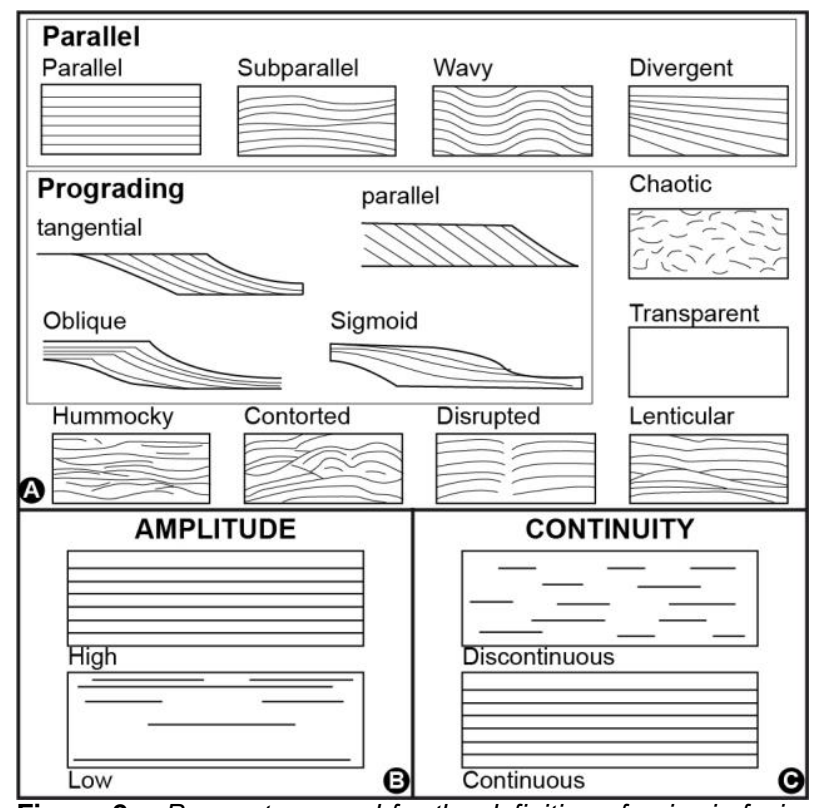

Figure 2 - Parameters used for the definition of seismic facies. (A) Configuration of reflectors. (B) Amplitude of the reflectors. (C) Continuity of reflectors. Modified from Mitchum et al., 1977.

A tool used for help for mapping reflectors and interpretation of the seismic facies is the seismic attributes - Step 2 (Figure 3). Seismic attributes are resources applied to seismic data in order to highlight stratigraphic units, structural features, lithological predominance and depositional systems. In order to recognize patterns across the seismic dataset, different complex attributes (sensu Taner \& Sheriff, 1977) and attribute combinations have been applied. Specifically the use of some attributes, such as, cosine of the phase, sweetness $X 2$ Trace AGC, RMS amplitude and relative acoustic impedance, have been crucial to resolve some of the internal seismic expression.

Also, based on seismic facies, is included here one of the most important techniques to provide exploratory data: the rock to seismic connection. It means the correlation of rock data, usually obtained by well drilling, to seismic environment parameters. By checkshot connection, synthetics analysis, or any other procedure, a well to seismic tie is necessary to get more integrated, detailed and confident information to the seismic facies (Alvarenga 
et al., 2016). Lithological groups, compositional changes, depositional settings and diagenetic variances may reflect, from simple to complex interaction, on seismic facies characterization.

\begin{tabular}{|l|l|l|l|}
\hline \multicolumn{1}{|c|}{$\begin{array}{c}\text { Seismic } \\
\text { Attribute }\end{array}$} & $\begin{array}{l}\text { Utility } \\
\text { Interpretation } \\
\text { Rule }\end{array}$ & $\begin{array}{l}\text { Visual } \\
\text { expression }\end{array}$ \\
\hline Sweetness & $\begin{array}{l}\text { Shadow and bright } \\
\text { areas to map the rift } \\
\text { section }\end{array}$ & $\begin{array}{l}\text { Use the } \\
\text { boundaris of } \\
\text { shadow and } \\
\text { bright areas }\end{array}$ \\
\hline $\begin{array}{l}\text { Cosine } \\
\text { Phase }\end{array}$ & $\begin{array}{l}\text { Continuity of reflection } \\
\text { patterns and fault } \\
\text { visualization }\end{array}$ & $\begin{array}{l}\text { Use the boundary } \\
\text { between patterns }\end{array}$ \\
\hline $\begin{array}{l}\text { RMS } \\
\text { Amplitude }\end{array}$ & $\begin{array}{l}\text { Enhances seismic } \\
\text { facies } \\
\text { and evainly for carbonates } \\
\text {-good to map the base } \\
\text { of salt }\end{array}$ & $\begin{array}{l}\text { Makes peak \& } \\
\text { trough as (+) }\end{array}$ \\
\hline $\begin{array}{l}\text { RAl: } \\
\text { Relative } \\
\text { Acoustic } \\
\text { Impedance }\end{array}$ & $\begin{array}{l}\text { Enhances seismic } \\
\text { facies } \\
\text { - mainly for carbonates } \\
\text { and evaporites } \\
\text { - good to map the base } \\
\text { of salt } \\
- \text { together with cosine } \\
\text { phase, to map faults }\end{array}$ & $\begin{array}{l}\text { Inversion of peak } \\
\text { \& trough } \\
\text { P-(-); } \mathrm{T} \text { - (+) } \\
\text { Enlarge the } \\
\text { reflection } \\
\text { frequency } \\
\text { Highlight the } \\
\text { texture }\end{array}$ & \\
\hline
\end{tabular}

Figure 3 - Synthetic overview of the seismic attributes applied and a description of their utility and interpretation rules used in Campos Basin - rift section.

Step 4: characterization and interpretation of the controlling variables of the stratigraphic interval

This step comprises the recognition of controlling variables for the depositional events, and also for the erosive events (unconformities). This is a more theoretical procedure, and depends for the available theories which fit best on the data and interpretations made on previous steps. Due to this spearhead status, it may constantly change according to new ideas, new proposals and theories as science is a never ending challenge. Here we can raise the recent advances of Catuneanu et al. (2009) and Catuneanu (2019) for the Sequence definition (depositional, genetic, T-R, and other variables), and the stacking patterns and nested sequence stratigraphy of Neal \& Abreu (2009).

On this step also, stacking patterns are recognized and their controlling variables are defined - eustatic, tectonic, climatic or anyone else.

\section{Step 5: chronostratigraphic chart}

The last step is the construction of chronostratigraphic chart, as originally pictured by Wheeler (1958). This step consists on make integration with all data show in a chronostratigraphic diagram - vertical geological time based. The diagram summarizes the erosive events, depositional packages and their filling, as well as their filling patterns (seismic facies) and depositional trends and controlling variables.

The integration of sedimentological data (core, petrological data (thin sections), and seismic stratigraphic (seismic stratigraphic units, seismofacies and chronostratigraphic charts) allows the establishment of a stratigraphic framework, formed by surfaces considered fundamental and mappable in the study area. So, the chronostratigraphic chart is the best integrative way to give a whole scenario of the data.

\section{Study Case - Geological context of Campos Basin}

The database used for demonstrated this methodology comprises a 2D seismic line (from the ANP database, and shared for research on UFRGS by BG Brasil) of the Campos Basin in specific rift section.

The Campos Basin is part of the Brazilian eastern margin basins trend, which have a geological evolution characterized by three distinct geotectonic phases (Chang et al. 1990), an initial pre-rift phase, dominated by intracontinental syneclisis style in the Late Jurassic, an Early Cretaceous rift phase, where the extensional regime was intense, including the break-up of Gondwana and a post-rift phase of continental drift and development of a passive margin, which started in the Albian and continues nowadays. The Campos Basin extends from the Cabo Frio High on south, to Vitória High on north, at Rio de Janeiro to Espírito Santo states (Figure 4). Covering an area of $115,800 \mathrm{~km} 2$, the Campos Basin has a limited onshore area of $5800 \mathrm{~km} 2$, with the majority located offshore.

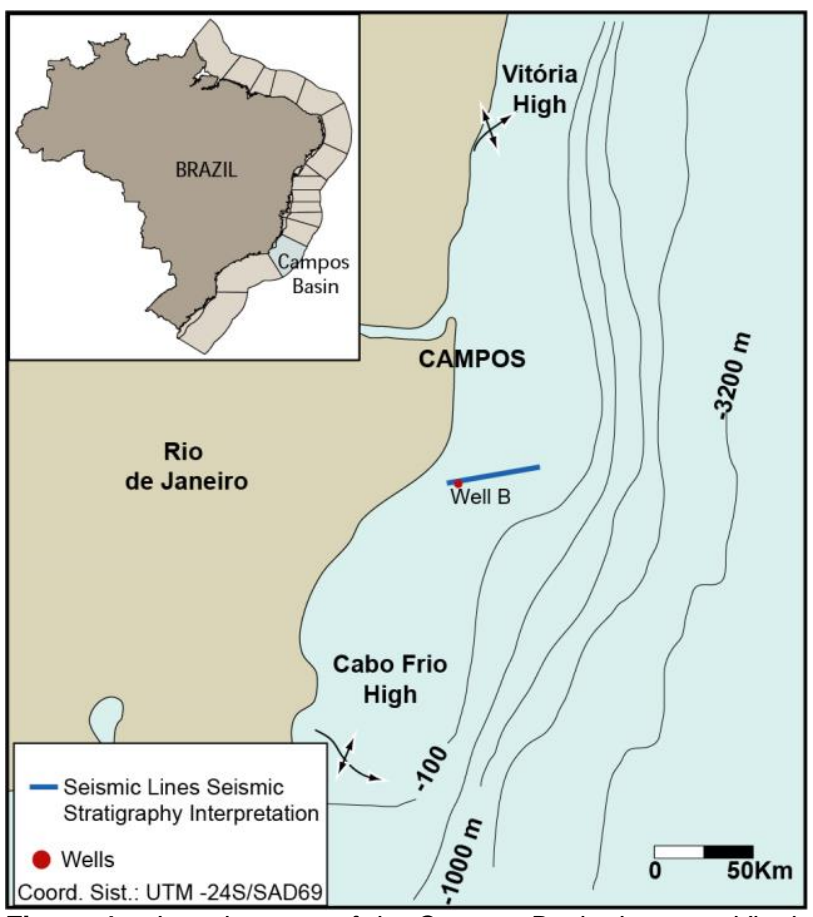

Figure 4 - Location map of the Campos Basin, between Vitoria High and Cabo Frio High with seismic line 2D and well used. Modified from Moraes, (1989).

Winter et al. (2007) was subdivided in the Atafona, Itapaboana, Coqueiros, Macabu, Gargaú and Retiro formations (Figure 5). The Atafona and Coqueiros formations corresponds to the rift phase, while the Itapaboana, Macabu and Gargaú formations are related to the pre-drift (sag) phase (Winter et al., 2007). The rift section, studied in this work, is characterized by conglomerate with basalt clasts, fan-delta and aprons deposits associated with the border faults, fine to coarse sandstones, shales rich in organic matter and siltstones 
(Atafona Member) and rudstones/grainstones (Coqueiros Member). The best porous facies are in rudstones/grainstones, with thickness up to 200 meters. These rocks characterize continental deposition in a lacustrine environment. The rudstones/grainstones are bioconcentrated, composed of bivalves and ostracods with little reworking, and represents the best pre-salt reservoirs of the rift section (Abrahão \& Warme, 1990). The top of the Lagoa Feia Group, comprising the sag phase, is composed of thick continental sediments, with conglomerates of Aptian age and red shales of Late Aptian age that grade to carbonates (chemical precipitates and microbial, on laminated or growns) overlied by evaporites of the Retiro Member, with rhythmic interbedded halite and anhydrite (Grassi et al., 2004).

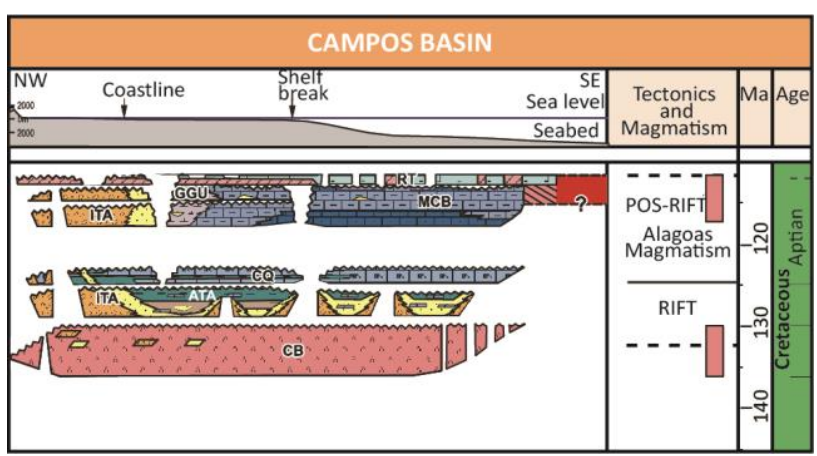

Figure 5 - Stratigraphic chart of the rift section in the Campos Basin. The end of the rift section varies according to each author. Modified from Winter et al. (2007). (CB = Cabiúnas Fm., ITA = Itapaboana Fm., ATA = Atafona Fm, CQ = Coqueiros Fm., GGU = Gargaú Fm., MCB = Macabu Fm., RT = Retiro Fm.).

\section{Study Case - Results}

Seismic stratigraphy analysis as stated above was performed on one 2D seismic line, in two-way time travel (milliseconds). Through the configuration of geometric patterns, amplitude, frequency and continuity of the reflectors, reflectors were mapped and their terminations that define the top and bottom of the rift troughs and border faults were identified.

\section{Step 1: interpretation of reflectors}

Through the configuration of geometric patterns, amplitude, frequency and continuity of the reflectors, reflectors were mapped and their terminations that define the top and bottom of the rift troughs and border faults were identified. A systematic mapping of all the reflectors and their terminations in whole syn-rift section (Figure $6 \mathrm{~A}$ and $B$ ) has performed. The base of the interval is the top of the Cabiúnas Fm. Volcanics, and the top of the interval is the Aptian unconformity that divides the syn-rift and the sag phases. The main structure is a half-graben, with a border fault on east and flexural margin at east.

\section{Step 2: definition of seismic stratigraphic units}

The interpretation of successive terminations of the reflectors in specific surfaces allowed the characterization of twelve seismic stratigraphic units - SU, (Figure $6 \mathrm{C}$ ). Seismic stratigraphic units are depositional units related to different time based events (Mitchum et al., 1977). Sometimes, they are separated by stratigraphic surfaces and other times, they mark only successive depositional events without changes in patterns and trends.

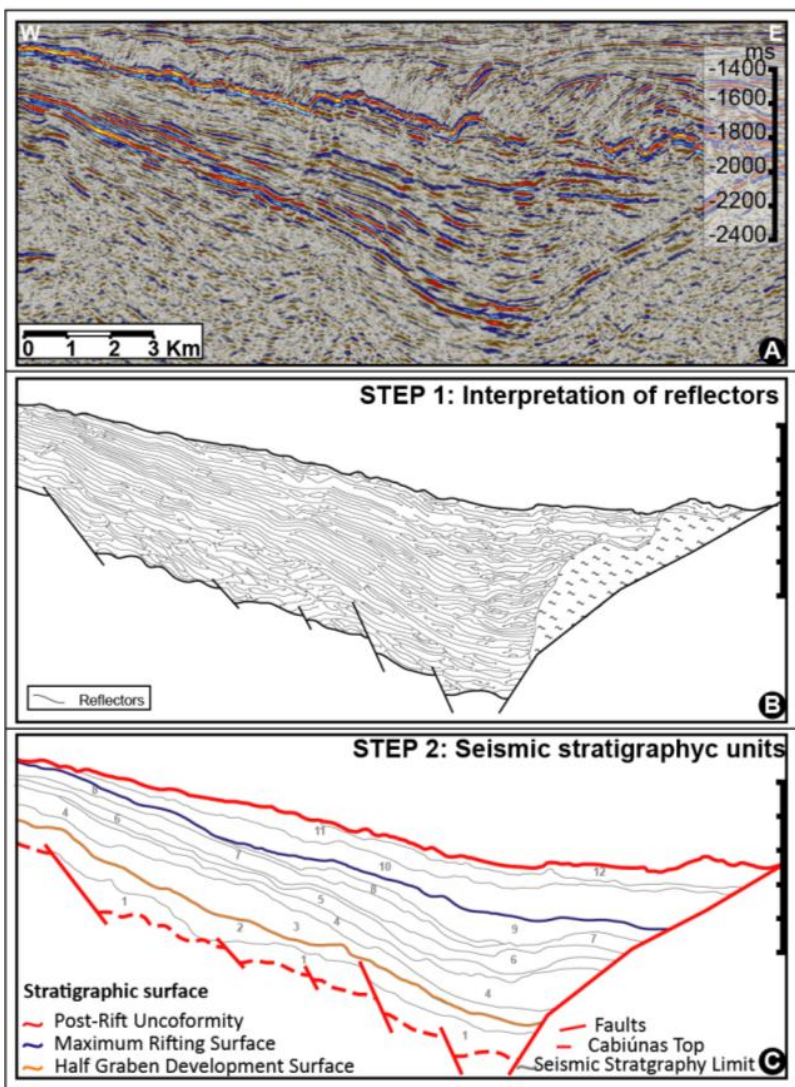

Figure $6-A$ ) In normal phase without interpretation. B) With reflectors interpretation. C) With interpretation of Seismic stratigraphic units.

\section{Step 3: seismic facies characterization}

Seismic and well data were gathered to characterize a set of three dimensional seismic units, comprising groups of reflectors whose parameters of their waves differs from adjacent units facies, these units are called seismofacies (as Mitchum et al., 1977). The main types of seismic features used in this mapping are: seismic amplitude, geometry of reflectors, continuity of reflectors and, when possible, their seismic frequency properties. For this, several attributes applied to these properties were used. The information obtained from seismic recognition and well data were used to construct a seismic facies model, covering the whole area investigated, and capable of correlation to determine the lithological composition of the general seismofacies.

The geological significance of the three recognized seismofacies was based on exploratory wells drilled near to the seismic sections analyzed. Goldberg et al. (2017) presented a sedimentological interpretation for the observed lithology, from lithological composed log from wells and c. 300 meters of described cores. Basically, they comprise fine background lacustrine deposits, interbedded with re-sedimented deposits from shallower regions of the half-graben (not preserved). These resedimented deposits can be thin (where they are not 
distinguished from background sediment) or thick (usually rudstone/grainstones). Clastic conglomerates were also recognized related the boundary faults. This interpretation of Goldberg et al. (2017) is used in this study as the basis of the depositional systems and related seismofacies. The identification of seismofacies and their seismic characteristics are summarized in the Figure 7.

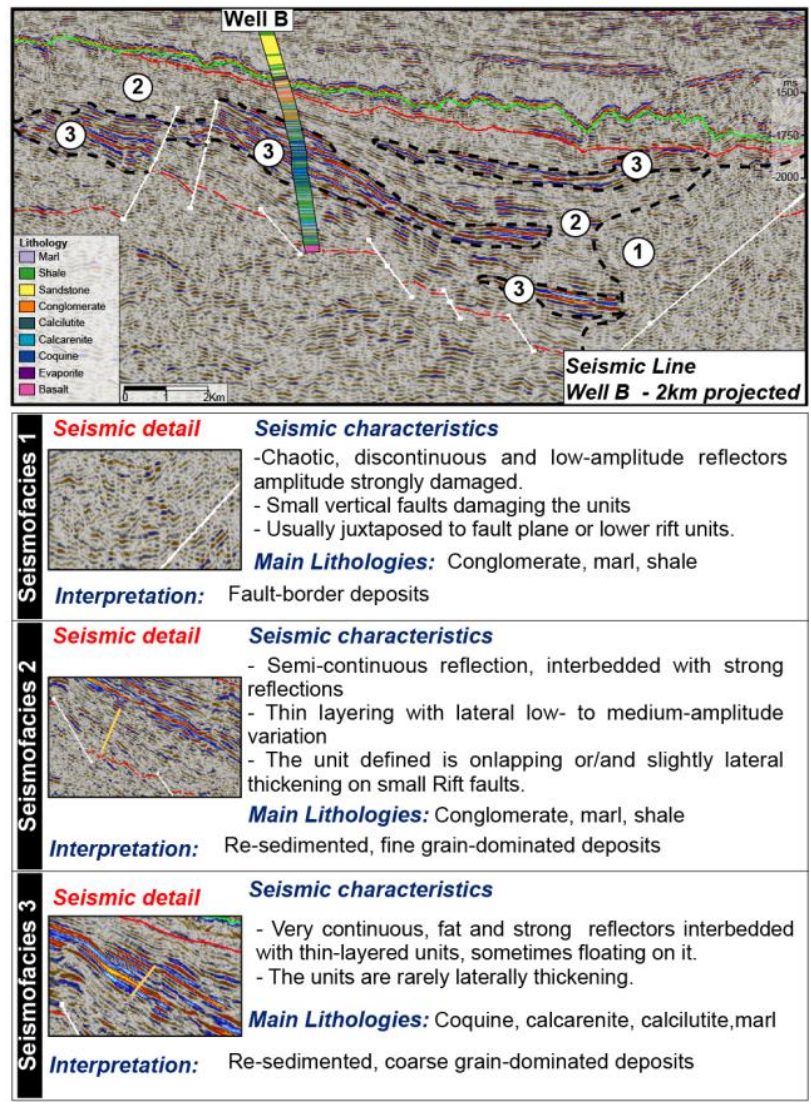

Figure 7 - Representative seismic section and description of the main seismofacies observed in rift interval of the Campos Basin.

\section{Step 4: characterization of interval controllers}

The identification of surfaces that define seismic stratigraphic units is important, because some of these may represent change of events depositional and is held from observing changes on stacking patterns or trends between seismic stratigraphic units. Key surfaces have been identified that show lateral continuity along structures. These key surfaces were defined from reflectors seismic, ending with identification of onlaps, downlaps, toplaps and erosive truncation. Thus, mapping the horizons defined the rift interval (1) syn-rift: Cabiúnas Formation top, as a basal surface and (2) Post-rift unconformity, top surface, which separates the syn-rift to sag section. Additionally, the salt base has mapped, as a functional surface for the control and positioning of the syn-rift section. Overall, the Cabiúnas Formation top and Post-rift unconformity horizons comprise the syn-rift section mappable in the study area, and their stratigraphic meanings will be discussed below. The relationship between the seismic stratigraphic units, based on geometric patterns and their spatial distribution, allowed us to determine and characterize intervals that comprise the seismic stratigraphic units, which were here termed as tectonic systems tract (Figure $8 \mathrm{C}$ and $\mathrm{B}$ ). Tectonic tract are sets of genetically related depositional systems (cf. Brown \& Fischer, 1977), which accumulated in a specific tectonic phase during the filling of a half-graben (cf. Prosser, 1993). None stacking pattern were recognized due to just border fault, and deep lacustrine deposits occurrence. The occurrence of coarse re-sedimented deposits just indicates a collapse of material merged on fine lacustrine sediments and do not implies on progradations or any stacking pattern definition.

But, based on reflection patterns - parallel, divergent and the main erosions on flexural margin, three stratigraphic stages were defined. At base (on blue at Figure 7B, and SU 1-2 on Figure 7C), the Rift Initiation System Tract, showing the beginning of the rifting, on a syneclisis fault controlled, but with no border fault, as proposed by Kuchle et al. (2011). This is followed by a High Tectonic System Tract (on green at Figure 7B, and SU 3-8 on Figure 7C), marked by highly divergent reflections and border faults advance deposits. The ending unit - Low Tectonic System Tract (on yellow at Figure 7B, and SU 912 at figure $7 \mathrm{C}$ ), is marked by more parallel reflections and retreating of the border fault deposits.

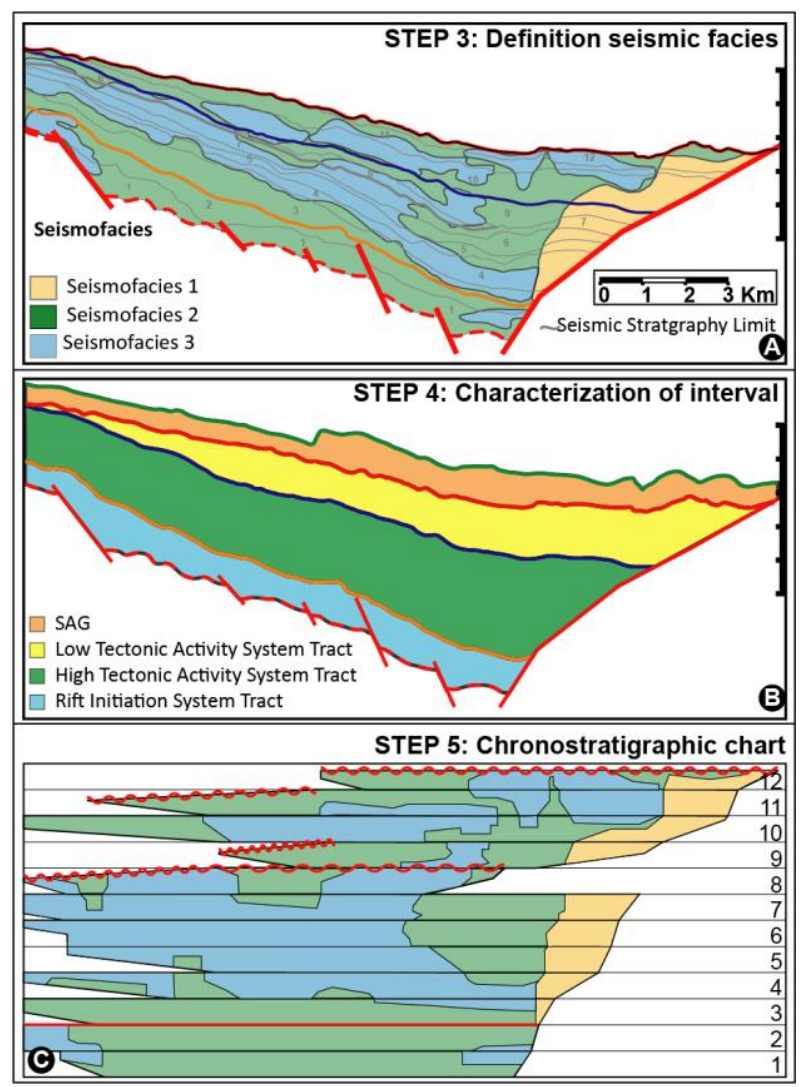

Figure 8-A) Interpretation integrated with seismofacies, seismic stratigraphic units and surfaces. B) Interpretation and delimitation of the Systems Tract. C) Chronostratigraphic diagram.

\section{Step 5: chronostratigraphic chart}

Interpretation of the seismic line allowed construction of a chronostratigraphic chart, (Figure 8C). This chart integrated all the interpreted data, the stratigraphic units, that are distributed in time slices - for each SU, and the 
seismofacies, (Figure 7 and Figure 8), resulting in a clear temporal and spatial distribution of units and infills defined by seismic data. Interpretation of the chronostratigraphic chart allows us to define regionally significant surfaces which mark erosions or periods of non-deposition. The complete chaotic distribution of the coarse grained (grainstones and rudstones) bioclastic mixed deposits (on blue at Figure 7C) shows a gravitational-based collapse of material and merging patterns with the fine grained background lacustrine deposits (on green). Also, shows the advancing and retreating of the border fault deposits (on beige).

\section{Final remarks and exploratory impacts}

The proposed procedure aims to extract the maximum and best reliable information from seismic data to provide more confident elements to exploration of petroleum, especially on poorly known areas, or data coverage. This procedure is not dependent of controls or tectonic styles, and can be fitted to provide time slicing and depositional events across stratigraphic units. Also, no order-detail is necessary, and from regional to high resolution data can be used. Clear and follow up step sequence allows different professionals to perform stratigraphic analysis on geographical adjacent areas or basins, and integrates easily and simple data and geological interpretations. At last, it is not theory dependent. So, new model and theories can reset the interpretations with no data or characterization discard.

\section{Acknowledgments}

We acknowledge mainly to Programa de Pós-Graduação em Geociências da Universidade Federal do Rio Grande do Sul (PPGGEO UFRGS), CNPQ, CAPES and ANP for institutional and National research support, for the Programa de Recursos Humanos - ANP $(\mathrm{PRH})$ for the granting of undergraduate, master's and doctoral scholarships to Brazilian Universities. Also to Petrobras, Shell Energia \& BG Brasil, Chevron, Maersk Oil and all companies that invested in research on a voluntary or mandatory basis under the ANP's PDI clauses.

\section{References}

ABRAHÃO, D., \& WARME, J.E. 1990. Lacustrine and associated deposits in a rifted continental margin-lower Cretaceous Lagoa Feia Formation, Campos Basin, Offshore Brazil. in Lacustrine Basin Exploration, Case Studies and Modern Analogs, Vol. 50, pp. 287-305, ed. Katz B.J., AAPG Memoir.

ALVARENGA, R.; IACOPINI, D.; KUCHLE, J.; SCHERER, C.; GOLDBERG, K. 2016. 'Seismic characteristics and distribution of hydrothermal vent complexes in the Cretaceous Offshore Rift Section of the Campos Basin, Offshore Brazil. Marine and Petroleum Geology, 74, 12-25.

BROWN, L. F., JR.; FISCHER, W. L. 1977. Seismic Interpretation of Depositional Systems: Examples from
Brazilian Rift and Pull-Apart Basins. 1977. Seismic Stratigraphy - applications to hydrocarbon exploration. Tulsa: American Association of Petroleum Geologists. AAPG Memoir 26. P. 213-248.

CATUNEANU, O. et al. 2009. Towards the standardization of sequence stratigraphy. Earth-Science Reviews. N.92, p. 1-33.

CATUNEANU, O. 2019. Model-independent sequence stratigraphy. Earth-Science Reviews. N.188, p. 312-388.

CHANG, H. K.; BENDER, A. A.; KOWSMANN, R. O.; MELLO, U. T. 1990. Origem e evolução termomecânica de bacias sedimentares. Origem e Evolução de Bacias Sedimentares. PETROBRAS, Rio de Janeiro. p. 49-71.

GRASSI, A. D. A.; CASTRO, A. H. A.; AlBERTÃO, G. A. 2004. Bacia de Campos. PHOENIX, 65: 1-6

GOLDBERG, K.; KUCHLE,J.; SCHERER, C.; ALVARENGA, R.; ENE, PL.; ARMELENTI. G.; DE ROS, L. F. 2017. Re-sedimented deposits in the rift section of the Campos Basin. Marine and Petroleum Geology 80, 412-431

KUCHLE, J.; \& SCHERER, C. M. S. 2010. Sismoestratigrafia de bacias rifte: técnicas, métodos e sua aplicação na Bacia do Recôncavo. Boletim de Geociências da Petrobras, v.18, n.2, p.179-206.

KUCHLE, J.; SCHERER, C.M.S.; BORN, C.C.; ALVARENGA, R.S. \& ADEGAS, F. 2011. A contribution to regional stratigraphic correlations of the Afro-Brazilian depression - The Dom João Stage (Brotas Group and equivalent units - Late Jurassic) in Northeastern Brazilian sedimentary basins. Journal of South American Earth Sciences. 31, 358-371.

MITCHUM JR., R.M., VAIL, P.R., SANGREE, J. B. 1977. Seismic stratigraphy and global changes of sea level, Part 6: Stratigraphic interpretation of seismic refletion patterns in depositional sequences. In: Payton, C.E. (ed.). Seismic Stratigraphy - Applications to Hidrocarbon Exploration. Tulsa, AAPG, 117-133 (Memoir \# 26).

NEAL, J. \& ABREU, V. 2009. Sequence stratigraphy hierarchy and the accommodation succession method. Geology, 37(9), 779-782.

TANER, M. T., \& SHERIFF, R. E. 1977, Application of amplitude, frequency, and other attributes to stratigraphic and hydrocarbon determination, in Payton, C. E., Ed., Seismic stratigraphy-applications to hydrocarbon exploration: AAPG Memoir, 26, 301-327.

VAIL, P. R. \& MITCHUM JR., R. M. 1977b Overview. Seismic stratigraphy - applications to hydrocarbon exploration. Tulsa: American Association of Petroleum Geologists. American Association of Petroleum Geologists. Memoir, 26, 51-52.

WHEELER, H.E. 1958. Time-Stratigraphy. Bulletin of the American Association of Petroleum Geologists. 42(5), 1047-1063.

WINTER, W. R.; JAHNERT, R. J.; FRANÇA, A. B. 2007. Bacia de Campos. Boletim de Geociências da Petrobras, 15( 2), 511-529. 